\title{
Effects of oil pollution on vegetation, potentially useful indicator species for rehabilitation
}

\author{
IULIANA FLORENTINA GHEORGHE ${ }^{1 *}$, SORANA IONESCU $(\text { ŢOPA })^{2}$, DANIELA STRAT ${ }^{3}$ \\ ${ }^{1}$ Faculty of Ecology and Environmental Protection, Ecological University of Bucharest, Bd Vasile Milea, \\ $1 \mathrm{G}$, Bucharest, Romania \\ ${ }^{2}$ Oil and Gas Engineering Faculty, Petroleum-Gas University of Ploieşti, Bd Bucureşti, no. 39, Ploieşti, \\ 100680, Romania \\ ${ }^{3}$ University of Bucharest, Faculty of Geography, Bd N. Bălcescu 1, Sector 1, 010041 Bucharest, Romania
}

\begin{abstract}
In Romania there are many types of historical oil soil contamination the most important beingthe land ones in Prahova County. The damage caused by this pollution may be permanent and takes a long time to remedied, sometimes requiring the ecological reconstruction of the polluted area. A major role in the remediation of soils polluted with oil plays the vegetation, some plant communities having a higher capacity to adapt and accelerate the process of mineralization of oil, hurrying decontamination. The goal of this paper was to realize an inventory of the oil-contaminated zones in Prahova County (historical oil pollution areas), to study the vegetation cover structure in selected representative sites and to identify potentially useful indicator species in terms of the ability to grow in extreme conditions for ecological restoration and remediate contaminated soils. Inventory of oil contaminated areas and historical data collection related to polluted areas and type of pollution were recorded. The vegetation studies have also been carried out in these areas. The richness of species in areas contaminated with oil is low (44 plant species - Tintea respectively 49 - Pisculești, forming two different plant communities structure (Jaccard similarity index of about 1\%) with low biomass production and productivity (338 DW/sqm). The number of nitrogen fixing plants is higher at Pisculeşti (6) compared to Ţintea (4) which can be explained by the fact that the nitrogen soil content at Pisculeşti is much less than at Tुintea. The conclusion was that the plants recommended for use in the reconstruction of historically polluted areas with oil, must have a genetic structure that enables them to adapt a high plasticity in terms of metabolism and root absorption, availability of absorption at radicular level in relation with chemical nitrogen forms. The most important are the plant species that develop the nitrogen fixation formations with different bacterial species.
\end{abstract}

Keywords Oil-contaminated zones, vegetation structure, biomass, nutrient uptake.

To cite this article: GHEORGHE IF, IONESCU (TOPA) S, STRAT D. Effects of oil pollution on vegetation, potentially useful indicator species for rehabilitation. Rom Biotechnol Lett. 2020; 25(1): 1186-1193. DOI: 10.25083/rbl/25.1/1186.1193 


\section{Introduction}

Oil spill is the release of a liquid petroleum hydrocarbon into the environment, on terrestrial or marine areas, due to human activity; it happens due to human negligence and is a form of pollution. The sources of the spill are many; crude oil can be released by tankers oil wells, of shore and terrestrial oil platforms. Different types of ecosystems in the area are at the risk of petroleum and brine contamination because of accidental spills, leaks or discharges due to the presence of many refineries and oil wells. Romania was one of the most important exporters of petroleum products (placed on $6^{\text {th }}$ place in the world in 1928). In 1918 during the first world war were destroyed by command 1677 oil wells, 26 refineries and many tanks and manufactories (CALCAN [17]). During the Second World War the town was an important target of the air raids, during which the most parts of the industrial objectives were destroyed. All these historical events caused heavy oil pollution in the area and the nowadays contaminated zones (especially groundwater pollution) correspond to the old industrial objectives destroyed. The oldest oil field in the area was recorded in 1785 and the first refinery was built at Rifov in 1856 (*[18]). In 1862 the first well for oil extraction was built in Prahova region. The Prahova region was and still is one of the most affected areas by oil pollution from the country. Prahova region recorded a yearly production of crude oil at that time of about $1475503 \mathrm{t}$ (CALCAN [17]; PIZANTY [19], [20], [21]), comparable to a yearly production of crude oil of $461000 \mathrm{t}$ in 2007 (NIS [22]). Nowadays, the crude oil processed in refineries from Prahova area is about $301608 \mathrm{t} / \mathrm{month}$.

In 1939, the refineries from Ploieşti (twelve at number) processed $80 \%$ from the entire quantity of crude oil extracted in Romania (CALCAN [17]; [19]). Because of that, the area was a strategic objective during the first and the second world wars (** [23]). Knowledge about the effects of oil pollution on vegetation has been largely based on aquatic biocenoses, such as salt marshes, mangrove forests or other aquatic organisms (GREEN [1]; NICOLOTTI [2]; KE \& al [3]). Very little is known about the effect of oil on the soil and its microorganisms, such as mycorrhizal fungi, and the resulting indirect effects on plants. Oil pollution of soil affects vegetation negatively, however, under certain circumstances; low-level contamination of mineral oil constituents (less than 1\%) does not inhibit plant growth (GUNTHER [4]). In some cases, the growth of certain plants can also be stimulated by crude oil. Growth stimulation can be a result of the direct release of nutrients or growth regulating compounds from the oil or to the release of nutrients from animals and bacteria killed by the oil (NICOLOTTI [2]; LIN [5]).

The differential sensitivity of plants to oil toxicity is well known. Responses of plants to oil contamination differ with species, and thus, oil pollution may change community species composition. Oil contamination may affect plants by retarding seed germination, reducing plant height, stem density, photosynthetic rate and biomass or resulting in complete mortality (LIN [5], [6]). The effects of oil on the vegetation can be grouped into: a) direct effects on plant growth, either through a reduction in gas exchange and light reception due to oil deposition on the leaves, or to physiological disturbances, affected by oil compounds taken up through stomata or roots (McCLAUGHERTY \& al [7]); b) indirect effects on plant growth, either due to oil-mediated environmental changes, such as a stimulated $\mathrm{N}$-fixation, soil anaerobiosis, shifts in interspecific competitive relationships, or to oil-induced changes in the level of tolerance of environmental stress factors (SCHOLTEN \& al [8]). Oil polluted vegetation can be perturbed for a long time. These perturbations are not only determined by the amount of oil and retention rates, but also by shifts in competitive interactions and consequent shifts in vegetation structure. Experimental studies have shown that species that respond in an opportunistic way (i.e., have potential for recovery) become dominant and suppress the recovery of the other species (SCHOLTEN \& al [9]). Response of plant performance and root properties to heterogeneous distribution of crude oil pollutants and mycorrhizal colonization is poorly understood even though (high) heterogeneity represents the normal case rather than exception in re-vegetation and phyto-remediation of polluted soils. Apart from plant responses to homogeneous pollution (e.g., decreased absorption and root biomass) or mycorrhization (e.g., larger phosphorus contents in leaves), systemic interactions were identified between split roots of heterogeneous treatments (LANGER \& al [10]). Studies conducted by AMAKIRI \& ONOFEGHARA [11] investigated the effects of crude oil pollution on the seedling and subsequent growth phases of Zea mays Var. F27, (Corn) Abeimoschusesculentus (Okro) and Capsicum frutescens (Pepper). Zea mays seedlings and Capsicum plants were most susceptible to crude oil spillage in crops with plant density $31 / \mathrm{m}^{2}$. Mature Zea mays and Abelmoschusesculentus were fairly tolerant to crude oil doses of 31 individuals $/ \mathrm{m}^{2}$ and 61 individuals $/ \mathrm{m}^{2}$. In the spraying experiments crude oil was found to be a potent contact herbicide. Zea mays and Abelmochusesculentus were completely destroyed in one or two weeks by death and maceration of vegetation or by defoliation. Capsicum frutescens rapidly recovered from defoliation with a flush of new leaves and branches 3 weeks after oil treatment. Among other factors, the phytotoxic, hydrophobic and other stress imposing properties of crude oil were suggested as causes of death to plants. DARLINGTON \& VURE [12] evaluated the impact of crude oil pollution on natural regeneration of plant species in a major oil-producing community three areas: unpolluted site (US) polluted, untreated site (PUS), and polluted and treated site (PTS)-were purposively chosen for the study. Woody-plant species richness, abundance, and diversity were higher in the unpolluted site (US) seed bank than in the polluted and untreated site (PUS) and and polluted and treated site (PTS) seed banks. The highest number of nonwoody plants was observed in the US, followed by the PTS, and then the PUS. Both species richness and diversity of non-woody plants were highest at the US, followed by the PUS, and lowest in the PTS. Woody species in the US seed bank were $87.5 \%$ and $80 \%$ dissimilar with those of the PUS 
and PTS at $0-10 \mathrm{~cm}$ and $10-20 \mathrm{~cm}$ respectively. No variation was observed between woody species in the PUS and PTS seed banks. Non-woody species at 0-10 cm US seed bank were $73.08 \%$ dissimilar with those of PUS at the two soil depths and $81.48 / 88.46 \%$ dissimilar with those of the $0-10 / 10-20 \mathrm{~cm}$ of the PTS respectively. At $10-20 \mathrm{~cm}$, nonwoody species of the US were $69.66 \%$ dissimilar with those from each of the two soil depths in PUS; and 73.91/81.82\% dissimilar with those of $0-10 / 10-20 \mathrm{~cm}$ of the PTS respectively. Non-woody species variation between the PUS and PTS was higher at $10-20 \mathrm{~cm}$ than $0-10 \mathrm{~cm}$. The poor seed bank attributes at the polluted sites demonstrates that crude oil pollution negatively affected the natural regeneration potential of the native flora because soil seed banks serve as the building blocks for plant succession. Thorough remediation and enrichment planting are recommended to support the recovery process of vegetation in the polluted areas.A way to restore the grassy areas polluted with oil is the acetylene treatment of the respective surfaces. Chronic oil treatment resulted in visible damage to the higher plants parts; however, vegetationassociated acetylene, reduction was not different from the untreated control. Estimated rates were greatest near the surface; free-living bacterial $\mathrm{N}_{2}$ fixation activity averaged $2.23 \mathrm{mg} \mathrm{N}$ per $\mathrm{m}^{2}$ per day (range-undetectable to $365 \mathrm{mg} \mathrm{N}$ per $\mathrm{m}^{2}$ per day) in the untreated and $3.17 \mathrm{mg} \mathrm{N}$ per $\mathrm{m}^{2}$ per day (range $=$ undetectable to $564 \mathrm{mg} \mathrm{N}$ per $\mathrm{m}^{2}$ per day) in the oil-treated vegetation during the year. Vegetationassociated $\mathrm{N}_{2}$ fixation activity yielded highest overall mean rates (156 $\mathrm{mg} \mathrm{N}$ per $\mathrm{m}^{2}$ per day) (THOMSON \& WEBB [13]). The goal of this study is to identify the behavior of vegetal communities in oil-polluted areas, to identify plant species resistant to oil pollution, and recommending them in decontaminate historically polluted areas with oil.

\section{Materials and Methods}

Two sites were selected for study. The criteria used are type of ecosystems (pasture and floodplain of a river) type of pollution and oldness. The first site (Fig. 1) is located at Țintea $\left(44^{\circ} 55^{\prime} 3.05^{\prime \prime} \mathrm{N} ; 2^{\circ} 1^{\prime} 57.11^{\prime \prime E}\right)$, which is a depression in a hilly area, one of the oldest oil fields from Romania. The area is active, some of the oil well-being still functional.
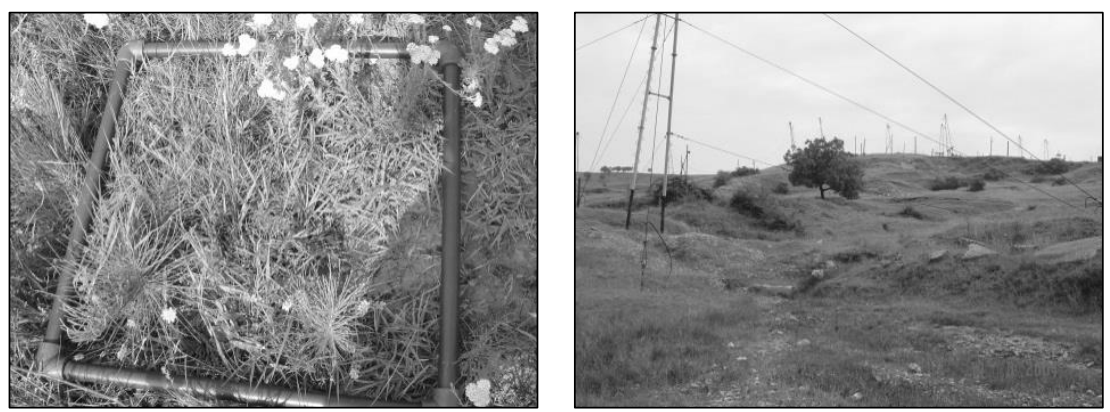

Figure 1. First site: Oil field Ţintea - general view

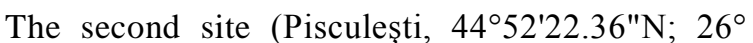
$\left.0^{\prime} 23.87^{\prime \prime} \mathrm{E}\right)$ is located within floodplain of the River Prahova, next to the discharge point of wastewaters of the Petrobrazi Refinery. Despite the fact that there is a filter station the discharge waters are still heavily contaminated. The color of the water (yellow-brown) and the smell around the discharge point emphasize this fact (Fig. 2).
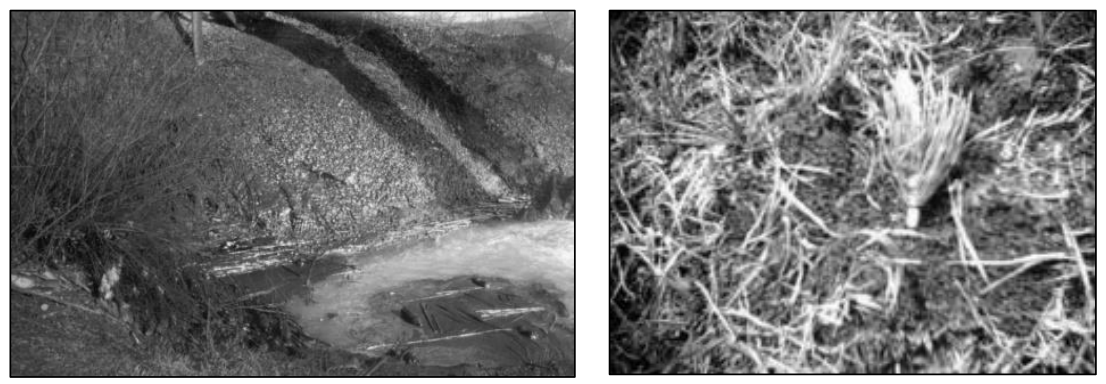

Figure 2. The second site: Discharge point of wastewaters from Petrobrazi Refinery

Structural analysis of vegetation was done in 2014 , during 4 months. To estimate the main structural parameters of vegetation four flora surveys were made in four moments (May, July, August and September). The following structural parameters of vegetation were estimated: species richness, land cover of vegetation, health of vegetation, biomass and productivity using the quadrate method. Size of quadrate is $50 * 50 \mathrm{~cm}$ (MILNER \& HUGHES [14]).
The species were separated into annual, biennial and perennial using the determination book (PRODAN \& BUIA [15]). The species richness was graphically analysis using Cholemman curve calculated with Multi-Variate-StatisticalPackage (MVSP) software, it represent the observed cumulative species richness in function of the cumulative number of quadrates. The production of low structured vegetation (herbaceous layer) was calculated by sequential 
sampling of plant material in the field. The dynamic of alive and dead biomass plant production measurements took place three times per year, on moment for each maximum of vegetation. Aboveground vegetation biomass and productivity were calculated only for Thintea site where the level of pollution is low and we decided to select this area as a target area for oil pollution. For the second site (Pisculeşti), only species richness, land cover and height of vegetation were recorded because plant communities are destroyed over 90. The aboveground biomass was harvested within the frame by cutting the shoots at the soil surface and the shoots were sorted into dead and living material. Samples have been dried for $48 \mathrm{~h}$ at $700 \mathrm{C}$ then weighted.

\section{Soil sampling and chemical analyse}

The following parameters were determined: Nitrogen, Phosphorus, Potassium (NPK), organic matter, Total Petroleum Hydrocarbon fractions C10 - C40 [TPH (C10 C40)] and TPH. All parameters were analysis at Institute for Risk Assessment Sciences (IRAS) Utrecht University.

Nutrient content of the soil was performed using Indophenol-Blue method, total phosphorus using the Greenmalachite spectrophoto-metric method and carbon using sulfo-chromic oxidative method (JONKER \& al [16]).

\section{Results and Discussio}

\section{Oil sources and polluted areas inventor}

The following major documented historical causes of oil pollution were identified in the Prahova County: a) Refineries (eight at number) destroyed during the second world war (1944-1945): Concordia Vega, SteauaRomână, Redeventa Xenia, Româno-Americană, Dacia România, Unirea Speranţa, Standard Petrol Block, Astra Română), causing soil and groundwater pollution (Petrostar SA, 1995); b) Damages to refineries, pipelines and other facilities during the earthquakes in 1940, 1977 and 1986; c) Deterioration during the operation at the transport pipes network, tanks or other equipments; d) Accidental or induced damages of the petroleum products transport pipes (administrated by Conpet, Petrotrans, Petrobrazi, Petrotel, Astra and Vega companies); e) Accidental oil-spills; f) Rain caused surface runoff of the petroleum products close to the processing oil equipment; g) Wear and tear of the equipment mainly of the tanks; h) Discharge of wastewaters from the refineries with petroleum products over the admissible levels and the use of this water in agriculture for irrigation. Concerning the oil pollution in the region, there is a major interest focused on the groundwater oil pollution. Most of the projects have as objectives the decrease of the level of groundwater pollution inside the Petrobrazi Refinery, development of a monitoring network for groundwater quality in the east-south east area of Ploieşti (PRAHOVA COUNTY COUNCIL AND PRAHOVA PREFECTURE [24]). Several bilateral projects (with external financing: PHARE, ECOLINKS) are attempting to decrease the pollution level in the southern part of the town where groundwater is heavily polluted (EPA [25]). In this area the petroleum layer from the groundwater flows on a northwest-southeast direction (which is the water flow direction) with a speed of about 50-200 m/year in the area of Petrotel, Petrobrazi and Vega refineries and about $25.5 \mathrm{~m} /$ year in the Astra refinery area (EPA [26]).

Major recent pollution events recorded lately include (EPA [25], [27]): a) Damage of the transport pipes of the petroleum products $\left(7795 \mathrm{~m}^{2}\right.$ in 2001 - arable land, ponds, access routes, forests affected); the surface of land affected by oil contamination due to the pipes damages decrease from $37,200 \mathrm{~m}^{2}$ in 2000 to $7,795 \mathrm{~m}^{2}$ in 2001. b) Spills from crude oil extraction areas (Băicoi, Boldeşti); c) Chronic pollution from "Petrotel-Lukoil” Refinery (739 ha), "Astra Română" Refinery and "Petrobrazi" Refinery (3478 ha), "Vega" Refinery (130 ha) and "Steaua Română", Câmpina. The soil-polluted layer has about 4-6 m depth from the surface and the thickness of the oil layer range in time and space from 0.01 to $3 \mathrm{~m}$.

\section{Soil proprieties}

The chemical analysis of sites soil samples revealed low levels of nitrogen compared to phosphorus and potassium. The low levels of nitrogen compared to phosphorus and potassium have been found in both sites that can be explained by an intense microbial activity (Table 1).

Table 1. Characteristics of the soil in the selected study sites

\begin{tabular}{|c|c|c|c|c|}
\hline & \multicolumn{2}{|l|}{ Tintea } & \multicolumn{2}{|l|}{ Pisculeşti } \\
\hline No. of samples & \multicolumn{2}{|l|}{10} & \multicolumn{2}{|l|}{7} \\
\hline Type of soil & \multicolumn{2}{|l|}{ Clay loam } & \multicolumn{2}{|l|}{ Sandy } \\
\hline Organic matter $(\%)$ & \multicolumn{2}{|l|}{$10.52 \pm 2.23$} & \multicolumn{2}{|l|}{$2.32 \pm 0.59$} \\
\hline Moisture (\%) & \multicolumn{2}{|l|}{$13.75 \pm 2.23$} & \multicolumn{2}{|l|}{$10.26 \pm 2.66$} \\
\hline Total N* (mg/g dry soil) & \multicolumn{2}{|l|}{$2.06 \pm 0.50$} & \multicolumn{2}{|l|}{$0.62 \pm 0.15$} \\
\hline Total P* (mg/g dry soil) & \multicolumn{2}{|l|}{$0.83 \pm 0.19$} & \multicolumn{2}{|l|}{$1.05 \pm 0.16$} \\
\hline Total $\mathrm{K}^{*}$ (mg/g dry soil) & \multicolumn{2}{|l|}{$6.36 \pm 1.66$} & \multicolumn{2}{|l|}{$6.08 \pm 1.14$} \\
\hline $\mathrm{TPH}\left(\mathrm{C}_{10}-\mathrm{C}_{40}\right)(\mathrm{mg} / \mathrm{kg}$ dry soil $)$ & $8.67 \pm 5.92$ & $\begin{array}{l}\min =2.25 \\
\max =20.27\end{array}$ & $116 \pm 155$ & $\begin{array}{l}\min =5.2 \\
\max =431\end{array}$ \\
\hline
\end{tabular}

* Kjeldahl; ** Values are expressed as Mean \pm SD

The higher presence of nitrogen fixing plants in oilpolluted areas is very common. The severity of the damage caused to the vegetation by the rupture of long hydrocarbon chains by microorganisms increases as the amount of nitrogen available decreases and mainly nitrogen-fixing plants can survive under these conditions (NICOLOTTI [2], 1998; GOGOI \& al [29]; MILLS \& al [30]). Nitrogen fixing plants such as legumes have been used to remediate 
contaminated soil, as nitrogen is a critical component in the mineralization of organic contaminants in soil. In case of petroleum contaminated soils, the added carbon stimulates microbial numbers but causes an imbalance in the soil $\mathrm{C}: \mathrm{N}$ ratio which may result in immobilization of soil nitrogen by the microbial biomass, leaving none available for plant growth. Legumes fix atmospheric nitrogen to produce their own source of nitrogen for growth; therefore, they may prove more successful at growing on petroleum hydrocarbon contaminated soils. In support of this statement, species of Fabaceae have been found to be the most abundant inhabitants of petroleum hydrocarbon contaminated sites (ADAM \& DUNCAN [31]). Plants recommended for use in the reconstruction of historically polluted areas with oil; must have a genetic structure that enables them to adapt and a high plasticity in terms of root absorption and availability of formation, nitrogen fixation formations with different bacterial species. The very low nitrogen concentrations in these polluted soils probably originated from the rapid biodegradation of hydrocarbons, which resulted in a significant nutrient uptake by micro-organisms. Usually, the presence of hydrocarbons in soils promotes intensive metabolic activity of the microorganisms not inhibited by the oil. Populations of hydrocarbon-degraders normally constitute less than $1 \%$ of the total microbial communities, but when oil pollutants are present these hydrocarbondegrading populations increase typically to $10 \%$ of the community (Atlas [28]). To confirm this hypothesis (low levels of nutrients, especially nitrogen, due to intense microbial activity) further research should be done. In this case, two types of stress might affect plants: (1) lack of nutrients which limit the growth and (2) the toxicity of hydrocarbons or other components used for crude oil extraction as for example, de-emulsifying chemicals and salt water in case of Thintea site or other components resulting from the processing of the crude oil in the refinery in case of Pisculeşti site. TPH (operationally defined as
$\left.\mathrm{C}_{10}-\mathrm{C}_{40}\right)$ in soil samples were quantified according to procedure reported by JONKER [16], using GC 8000 equipment (FisonsInstrumets). The results emphasize that at Tुintea there is a heavy oil pollution (concentrations range from $2911 \mathrm{mg}$ TPH/kg dry soil to $20279 \mathrm{mg} \mathrm{TPH} / \mathrm{kg}$ dry soil with a mean value of mean value of $8670 \mathrm{mg} \mathrm{TPH} / \mathrm{kg}$ dry soil) compared to Pisculeşti (concentrations range from $5.2 \mathrm{mg}$ TPH/ $\mathrm{kg}$ dry soil to $431 \mathrm{mg} \mathrm{TPH} / \mathrm{kg}$ dry soil with a mean value of $116 \mathrm{mg} \mathrm{TPH} / \mathrm{kg}$ dry soil), (Tab. 1, Fig. 3). Despite the fact that at Pisculeşti there is high amount of petroleum products discharged with waters from a refinery (strong smell, brown colour, and the thin oil layer on the surface of vegetation close to the discharge point) the TPH concentrations in the soil are relative very low. Very low nutrient concentration in the soil at Pisculești, associated with a high microbial activity, result in a high biodegradation rate that might compensate for the hydrocarbons input in the ecosystem. At the same time, low molecular weight hydrocarbons are evaporated and the characteristics of the soil (sandy soil and low organic matter content) facilitate the percolation of the hydrocarbons through groundwater. Heavy groundwater pollution has been reported for this area (EPA [26]). Regarding the oil fractions, the percentages are similar for both sites, the dominant fraction being the heavier one $\left(\mathrm{C}_{28}-\mathrm{C}_{40}\right)$, with a percentage of $50 \%$ for Țintea and $59 \%$ for Pisculeşti (Fig. 4). The percentages of oil fractions are only estimative, and are important in order to have a fair idea regarding the bioavailability of hydrocarbons since the success of bioremediation (TPH removal) depends largely on the contaminant characteristics. Therefore, it is essential to have a comprehension of the same in respect of total oil content and its constituents in terms of the different hydrocarbons present.

The soil analyses indicated a higher pollution at Țintea site. TPH $\left(\mathrm{C}_{10}-\mathrm{C}_{40}\right)$ average value is $8.7 \mathrm{mg} / \mathrm{g}$ dry soil and the maximum value of $20.3 \mathrm{mg} / \mathrm{g}$ dry soil.
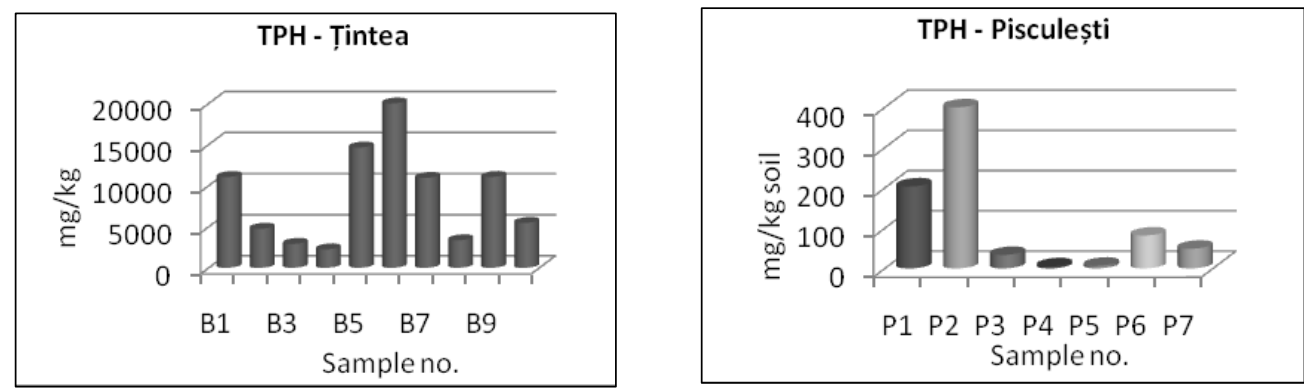

Figure 3. Total oil (TPH) (mg/kg dry soil) in soils from two selected sit.
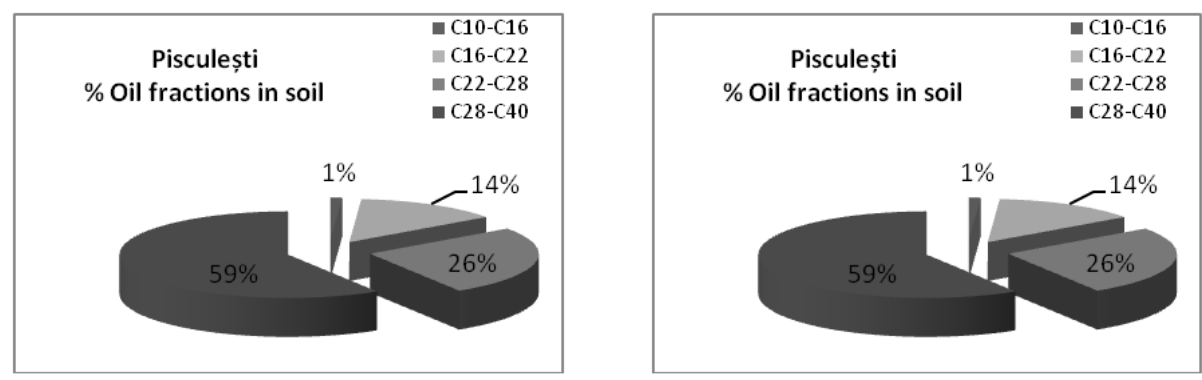

Figure 4. Oil fractions percentage in soils from thetwo selected sites. 


\section{Vegetation structure analysis (spring survey)}

The species richness was found to be similar for both sites (51 species for Țintea and 50 species for Pisculești). The diversity of herbaceous layer is high (47 species for Ţintea and 45 species for Pisculeşti). Perennial species are dominant in herbaceous layer (perennial/annual or biannual ratio $=1.76)$. Species richness, dominant species, land cover of vegetation, and health of vegetation values that were recorded are given in Table 2.

The soil analyses indicated a higher pollution at Ţintea site. TPH $\left(\mathrm{C}_{10}-\mathrm{C}_{40}\right)$ average value is $8.7 \mathrm{mg} / \mathrm{g}$ dry soil and the maximum value of $20.3 \mathrm{mg} / \mathrm{g}$ dry soil.

Table 2. The main results of the spring survey for the two sites (Ţintea and Pisculeşti)

\begin{tabular}{|l|l|l|}
\hline Parameter & Tintea & Pisculeşti \\
\hline Species richness & 44 & 49 \\
\hline Herbaceous species & 40 & 44 \\
Shrubs species & 4 & 3 \\
Tree species & - & 2 \\
\hline Species with frequency >50\% & Carexriparia & Elymusrepens \\
& Trifoliumcampestre & Viciahirsuta \\
& Equisetum arvense & Equisetum arvense \\
& Potentillareptans & Trifoliumcampestre \\
& Poapratensis & Trifoliumrepens \\
& Taraxacumofficinale & Daucuscarota \\
& Euphorbia peplus & Stellaria media \\
& Haleocharispalustris & \\
\hline Land cover \% & Plantago lanceolate & 69\% \\
\hline Medium height & 85\% & 13 cm \\
\hline
\end{tabular}

From the point of view of similarity the two areas are covered with different plant communities; less than $1 \%$ of dominate species are present in both types of vegetation (Fig. 5).

In August, plant specific diversity declined by half compared to May. This is due to the drought that was installed in August, when the precipitation amount was
$56 \mathrm{~mm}$, compared to $124 \mathrm{~mm}$ in May, and the maximum contribution of aboveground biomass in August was carried out by species adapted to dryness and oil pollution (Fig. 6). This statement is also supported by the degree of vegetation coverage that is higher in the Tintea site $(85 \%)$ to compare with Pisculeşti (69\%).

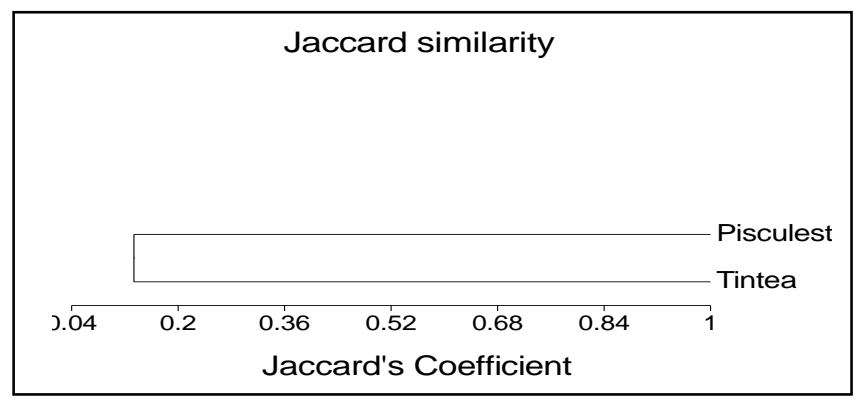

Figure 5. Jaccard similarity (number of species present in both areas Ţintea and Pisculeşti)
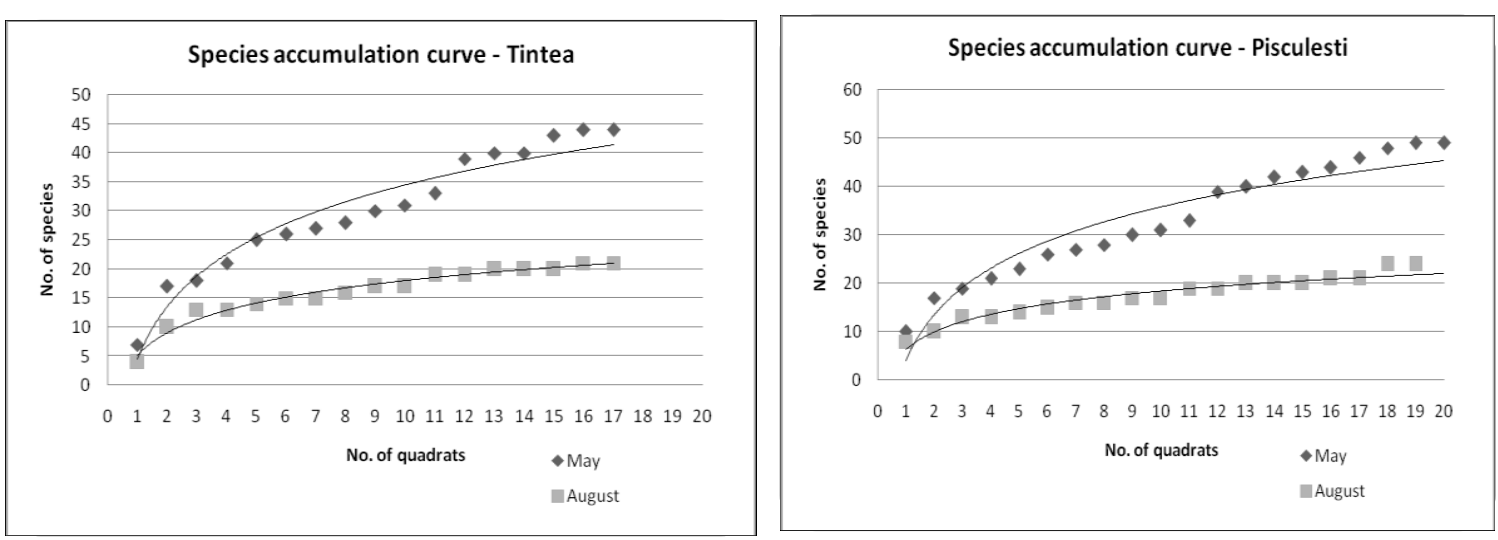

Figure 6. Species accumulation curve for 2 sampling: May and August moments. 
Aboveground vegetation biomass and productivity were calculated only for Tintea site where the level of pollution is high and we decided to select this area as a target area for oil pollution. The maximum of aboveground biomass for Tintea site was recorded in August with a mean value of $338 \mathrm{~g}$ dry weight $/ \mathrm{m}^{2}$.
The percentage of dead aboveground vegetation increases from 21\% in May and 23\% in August to a double value of $42 \%$ in September.

The increase proportion of dead above-ground biomass is due to the fact that between August and September no more live biomass is produced and some of it turns into dead biomass (productivity $=0$ ) (Table 3 and 4 ).

Table 3. Aboveground biomass

\begin{tabular}{|l|l|l|}
\hline & & Productivity \\
\cline { 3 - 3 } Time period & No. days & $\left(\mathrm{g} / \mathrm{m}^{2} / \mathrm{day}\right)$ \\
\hline July-August & 35 & 3.03 \\
\hline August-September & 22 & 0 \\
\hline \hline
\end{tabular}

Table 4. Productivity of aboveground vegetation

\begin{tabular}{|l|l|l|l|}
\hline \multirow{3}{*}{ Data } & Alive & Dead & Total Biomass \\
\cline { 2 - 4 } & $\mathrm{DW} / \mathrm{m}^{2}$ & $\mathrm{DW} / \mathrm{m}^{2}$ & $\mathrm{DW} / \mathrm{m}^{2}$ \\
\hline July & 185 & 47 & 232 \\
\hline August & 263 & 75 & 338 \\
\hline September & 93 & 61 & 154 \\
\hline
\end{tabular}

\section{Conclusion}

In areas polluted with oil the vegetation structure is simplified and the richness of species is reduced, only 49 . This is due to the fact that a small number of plant species have a high plasticity of metabolism enabling them to vegetate on polluted soils. The growth and development of plant individuals are also slowerwhich materialize through low biomass production and productivity (338 DW/sqm). At a first sight, the vegetation state indicates that it is subject to stress. The land cover of the herbaceous vegetation is lower compared to the surrounding areas, the height of plants is lower also than usual (comparative to data reported in the literature for these species) and there is quite a big percentage of necro-mass. The presence of nitrogen fixing plants was recorded in both sites. The number is higher at Pisculeşti (6); four of them are dominated species - Vicia hirsute, Trifolium campestre, Trifolium repens, Lens culinaris -compared to Țintea (4) one of them is dominated Trifolium campestre, which can be explained by the fact that the nitrogen soil content at Pisculeşti is much less than at Țintea. In ecological reconstruction, in historically polluted areas with oil it is recommended to use the vegetal communities in which the nitrogen-fixing plants are dominant. The proportion of the fraction present in the oil does not greatly influence the way that the oil affects the vegetation.

\section{Acknowledgements}

Results obtained within NWO Fellowship program (Cooperation between Oil-Gas University, Ploiesti Department of Engineering Environmental Protection and University Utrecht, Department of GeoBiology, Section Landscape Ecology). Many thanks for Prof. Dr. Jos
Verhoeven for supervising my work and for the entire support during my stage at the Landscape Department Utrecht University. Thanks, for good advices and helping to my project to: Dr. M. Jonker and Dr. J. Hermens (IRAS, Utrecht University), Dr. T.L. Pons (Faculty of Biology, Utrecht University).

\section{References}

1. D.A. GREEN, R. NAIMIMOHASSES, P.R. SMITH, H. THOMASON, In-situ measurements and classification of oil pollution. Environ. Int., 21 (2), 245, 250 (1995).

2. G. NICOLOTTI, S. EGLI, S., Soil contamination by crude oil: impact on the mycorrhizosphere and on the revegetation potential of forest trees. Environ. Pollut., 99, 37,43 (1998).

3. L. KE, T.W.Y. WONG., Y.S. WONG, N.F.Y. TAM, Fate of polycyclic aromatic hydrocarbon (PAH) contamination in a mangrove swamp in Hong Kong following an oil spill. Mar. Pollut. Bull., 45, 339, 347 (2002).

4. T. GUNTHER, Effects of ryegrass on biodegradation of hydrocarbons in soil. Chemosphere, 33(2), 203, 215 (1996).

5. Q. LIN, I.A. MENDELSSOHN, M.T. SUIDAN, K. LEE, A.D. VENOSA, The dose-response relationship between No. 2 fuel oil and the growth of the salt marsh grass, Spartinaalterniflora. Mar. Pollut. Bull., 44, 897, 902 (2002).

6. Q. LIN, I.A MENDELSSOHN, The combined effects of phytoremediation and biostimulation in enhancing habitat restoration and oil degradation of petroleum contaminated wetlands. Ecol. Eng., 10, 263, 274 (1998). 
7. C.A. McCLAUGHERTY, J.D. ABER, J.M. MELILLO, The role of fine roots in the organic matter and nitrogen budgets of two forested ecosystems. Ecology, 6, 1481, 1490 (1982).

8. M. SCHOLTEN, P. LEENDERTSE, P.A. BLAAUW , The Effects of Oil Pollution on Interacting Salt Marsh Species, Fate and Effects of Oil in Marine Ecosystems, 225-228 (1987).

9. M C.T. SCHOLTEN, P.C. LEENDERTSE, The impact of oil pollution on salt marsh vegetation, J. ROZEMA, J.A.C. VERKLEIJ, eds., Ecological responses to environmental stresses. Tasks for vegetation science, 22, Springer, Dordrecht, 1991, pp. 184-190.

10. I. LANGER, S. SYAFRUDDIN, S. STEINKELLNER, Plant growth and root morphology of Phaseolus vulgaris L. grown in a split-root system is affected by heterogeneity of crude oil pollution and mycorrhizal colonization. Plant and Soil, 332(1), 339, 355 (2010).

11 J.O. AMAKIRI, F.A. ONOFEGHARA, Effect of crude oil pollution on the growth of Zea mays, Abelmoschusesculentus and Capsicum frutescens. Oil and Petrochemical Pollution, 1(3), 199, 205 (1983).

12. U. DARLINGTON, G. VURE, Implications of crude oil pollution on natural regeneration of plant species in an oil producing community in the Niger Delta Region of Nigeria. J. For. Res. 25(4), 915, 921 (2014).

13. A.D. THOMSON, K.L. WEBB K, The Effect of Chronic Oil Pollution on Salt-Marsh Nitrogen Fixation (Acetylene Reduction). Estuar. Coasts., 7(1), 2, 11 (1984).

14. C. MILNER, R.E. HUGHES, Methods for measurement of the primary production of grassland, IBPhandbook, 6, (1968).

15. I. PRODAN, Al BUIA, Flora mică ilustrată a RPR. Editura Agro-Silvică, Bucureşti, 1961.16. M.T.O. JONKER, A.J.S. SINKE, J.M. BRILS, A.A. KOELMANS, Sorption of polycyclic aromatic hydrocarbons to oil contaminated sediment: unresolved complex?. Environ. Sci. Technol., 37, 5197, 5203 (2003).
17. GHEORGHE CALCAN, Industria petrolieră din România în perioada interbelică. Editura Tehnică, București, 1997.

18. *Studies and material on the historical past of Prahova county. County Committee for Culture and Art. History Museum of Prahova County, Ploiești.

19. M. PIZANTY, Situaţia României în comerţul mondial de petrol. Institutul economic românesc. Cartea Românească, București, 1936.

20. M. PIZANTY, Aria exploatării petrolifere în România. Cartea Românească, Bucureşti, 1938.

21. M. PIZANTY, (1938). Industria rafinajului în România. Cartea Românească, Bucureşti, 1938.

22. NIS (National Institute of Statistics), Romanian Statistical Yearbook, Bucureşti, 2007 (http://www. insse.ro/cms/files/Anuar\%20arhive/serii\%20de\%20da te/2007/ASR_2007.pdf

23. ** Local Agenda 21 - Local Plan of Sustainable Development of Ploieşti Municipality. City Hall of Ploieşti, 2002.

24. PRAHOVA COUNTY COUNCIL and PRAHOVA PREFECTURE, 2003.25. EPA, State of the Environment - report. Environmental Protection Agency, County Prahova, 2001.

26. EPA, Oil pollution of soil and groundwater in the area located south-east of Ploieşti - Report. Environmental Protection Agency - Prahova County, 1995.

27. EPA, State of the Environment - report. Environmental Protection Agency, County Prahova, 2002.

28. R.M. ATLAS, Bioremediation of petroleum pollutants. Int. Biodeterior. Biodegradation., 35 (1-3), 317, 327 (1995).

29. B.K. GOGOI, N.N. DUTTA, P. GOSWAMI, T.R.K. MOHAN, A case study of bioremediation of petroleumhydrocarbon contaminated soil at a crude oil spill site. Adv. Environ. Res., 7, 767,782 (2003).

30. M.A. MILLS, J.S. BONNER, T.J. MCDONALD, C.A. PAGE, R.L. AUTENRIETH, Intrinsic bioremediation of a petroleum-impacted wetland. Mar. Pollut. Bull., 46, 887, 899 (2003).

31. G.ADAM, H. DUNCAN, Influence of diesel fuel on seed germination. Environ, Pollut., 120, 363, 370 (2002). 